\title{
Bimbingan Konseling dan Pengurangan Kecemasan Terhadap Calon Jamaah Haji
}

\author{
Fajar Darmawan \\ ${ }^{1}$ Jurusan Bimbingan dan Konseling Islam, UIN Sunan Gunung Djati, Bandung \\ *Email:fajardarmawan@gmail.com
}

\begin{abstract}
ABSTRAK
Tujuan Penelitian ini adalah untuk mengetahui tentang peran bimbingan konseling dalam mengurangi kecemasan terhadap calon jamaah haji di KBIH Attaqwa Ujung Harapan Bahagai Kab. Bekasi dan untuk mengetahui hasil dari bimbibingan tersebut.adapun pertanyaan pneliti sebagai berikut Pertama bagaiaman kondisi psikologis calon jamaah haji di KBIH Attaqwa KH.Noer Alie Bekasi Kedua Bagaimana peran bimbingan konseling dalam mengurangi kecemasan terhadap calon jamaah haji di KBIH Attaqwa KH.Noer Alie Bekasi I hajikecemasan calonjemaahKetiga Bagaimana kondisi psikologis calon jamaah haji setelah mendapatkan bimbingan konseling metode yang digunakan dalam penelitian metode direct (metode langsung) melalui diskusi bersama dua arah dari pembimbing kepada peserta calon jamaah haji dan dari calon jamaah haji kepada pembimbing, kemudian pula melalui ceramah, metode observasi mengamati secara langsung dengan pengurus $\mathrm{KBIH}$, metode konsultasi yakni setelah melakukan observasi peserta didik diberikan kesempatan berkonsultasi dan konseling langsung dengan pengurus KBIH Berdasarkan penelitian yang dilakukan, dapat disimpulkan bahwa proses bimbingan konseling dapat menajdikan para calon jamaah haji lebih siap untuk melaksanakan ibadah haji. Dengan proses bimbingan konseling dapat menghilangkan kecamasan dan ketakutan pada saat calon jamaah haji melaksanakan ibadah haji di tanah suci.
\end{abstract}

Kata Kunci : Bimbingan; Konseling; KBIH; Jamaah haji.

\section{ABSTRACT}

The Purpose of this study was to find out about the role of counseling in reducing anxiety on prospective pilgrims at KBIH Attaqwa Ujung Harapan Bahagai District. Bekasi and to find 
out the results of the bimbibingan. One research question is as follows: First is the psychological condition of prospective pilgrims at KBIH Attaqwa KH. Noer Alie Bekasi Second What is the role of counseling guidance in reducing anxiety towards prospective pilgrims at KBIH Attaqwa KH. Noer Alie Bekasi Third What is the psychological condition of the prospective pilgrims after getting counseling guidance the method used in the direct method method through two-way joint discussion from the mentor to the prospective pilgrims and the prospective pilgrims to the supervisor, then through lectures, the observation method observes directly with KBIH management, the consultation method is after observing students are given the opportunity to consult and counsel directly with the KBIH management. Based on the research conducted, it can be concluded that the counseling process can make prospective pilgrims more ready to carry out the Hajj. With the process of counseling guidance can eliminate the anxiety and fear when prospective pilgrims perform the Haij in the boly land

Keywords: Guidance; Counseling; KBIH; Hajj Pilgrims.

\section{PENDAHULUAN}

Haji pada hakekatnya merupakan aktifitas suci yang diwajibkan oleh Allah kepada seluruh ummat islam yang telah mencapai (istitho'ah) mampu, disebut aktivitas suci karena seluruh rangkaian kegiatan adalah ibadah. Haji juga disebut sebagai ibadah puncak yang melambangkan ketaatan serta penyerahan diri secara total kepada Allah baik secara fisik-mental maupun spiritual.

Menurut KH. M. Amien Noer yang disampaikan pada seminar haji (tanggal: 13 Februari 2018) "Mampu" atau "Istitho'ah bidang kesehatan adalah mampu menunaikan ibadah haji ditinjau dari jasmani yang sehat dan kuat agar dapat melaksanakan perjalanan dan mudah melakukan proses ibadah haji, berkala sehat dan memeiliki kesiapan mental untuk menunaikan ibadah haji di arab Saudi, serta aman bagi keluarga (Lukman hakim saifudin)

Sebelum berangkat ketanah suci, calon jema'ah haji di haruskan untuk mempersiapkan segala sesuatunya baik materi, fisik, mental serta yang tak kalah pentingnnya adalah pengetahuan seputar haji yang biasaanya disebut dengan manasik haji. Perjalanan ibadah haji adalah perjalanan yang suci, disamping memerlukan biaya yang tidak sedikit, juga memerlukan kesiapan fisik dan mental serta pengetahauan tentang haji.

Namun faktanya peneliti menemukan fenomena dilapangan terdapat beberapa peristiwa calon jema'ah haji mengalami gangguan mental seperti: Pertama disebabkan psikologis seperti jauh dari keluarga dalam jangka waktu yang lama. Kedua di sebabkan rasa kehawatiran yang tinggi.Ketiga di sebabkan gangguan perasaan oleh terganggunya kesehatan mental yaitu kecemasan Keempat di sebabkan stress ringan akibat aghorophobia ialah takut melihat orang banyak.

Menurut hasil wawancara dengan Ustd Fauzi (tanggal: 1 january 2018) 
jumlah calon jemaah haji yang mengikuti bimbingan manasik haji pada tahun 2013 ada 100 calon jema'ah haji yang mengikuti proses bimbingan manasik haji namun dari 100 calon jema'ah haji ada 3 calon jema'ah haji yang mengalami gangguan psikologis karena rasa kecemasan dan kehawatiran yang sangat tinggi disebabkan jauh dari keluarga dengan jangka waktu yang lama. Dan takut ketika disana mereka tidak bisa bersosialisi dengan masyarakat di Arab Saudi.

Menurut hasil wawancara dengan Ustd Nur Anwar Amien (tanggal: 5 maret 2018) berdasarkan hasil hitungan beliau pada waktu menjadi pembimbing pada tahun 2015 jumlah calon jema'ah haji ada 125 calon jema'ah haji. ada 2 calon jema'ah haji yang bermasalah seperti; (1) disebabkan fisik serta psikologisnya sangat lemah pada akhirnya calon jema'ah haji ini tidak diberangkatkan karna di takutkan ketika di tanah suci merepotkan dan ibadahnya tidak optimal. Pada tahun 2017 jumlah calon jema'ah haji ada 104 calon jema'ah haji yang daftar di KBIH Attaqwa dan mengikuti bimbingan manasik. dari 104 calon jema'ah haji yang siap secara fisik, mental dan psikologisnya hanya 99 calon jema'ah haji, selebihnya itu kurang siap secara fisik, mental dan psikologisnya. Oleh karnanya kami dari pihak KBIH memutuskan untuk Mengadakan program Bimbingan secara husus yaitu bimbingan konseling secara kesehatan, psikologis dan mental dalam mengurangi masalah yang berkaitan dengan perasaan cemas, mental dan lain sebagainnya.

Gangguan perasaan yang disebabkan oleh terganggunya kesehatan mental diantaranya adalah kecemasan dimana kecemasan adalah menifestasi dari berbagai proses emosi yang bercampur baur yang terjadi ketika orang sedang mengalami tekanan perasaan (frustaasi) dan pertentangan batin (konflik).

Kecemasan itu mempunyai segi yang didasari rasa takut, terkejut dan tidak berdaya, rasa berdosa/bersalah, terancam dan sebagainya juga ada segi yang terjadi diluar kesadaran dan tidak bias menghindari perasaan yang tidak menyenangkan itu. Rasa cemas itu terdapat dalam semuah gangguan jiwa dan ada bermacam-macam

Menurut Zakiah Dardjat dalam bukunya kesehatan mental (2001: 8-9) menjelaskan bahwa keadaan yang tidak menyenangkan itu tidak terbatas kepada golongan tertentu saja, tetapi tergantung kepada cara orang mengahadapi sesuatu persoalan. Misalnya ada orang miskin yang gelisa karena banyak keinginannya yang tidak tercapai bahkan kebutuhan pokok saja idak bias dipenuhi. Sebaliknya ada pula orang kaya yang juga gelisah, cemas dan merasa tidak tentram dalam hidupnya tetapi sebab kecemasannya lain, bukan karena kekurangan uang melainkan oleh hal-hal lain seperti kebosanan, tidak tahu apa yang harus dilakukan uang banyak segalanya cukup. Atau pula ingin selalu menambah hartanya lebih banyak lagi. 
Masalah-masalah diatas ini sering dialami oleh para calon jamaah haji sebelum berangkat ketanah suci pada masa lansia yang ditandai penurunan kodisi fisiologis, psikologis karna sisebabkan kecemasan maupun mental dapat disimpulkan bahwa pada masa lansia masalah pribadi ini timbul karena individu tidak tau kurang berhasil dalam mempertemukan antara aspek-aspek pribadi disatu pihak dan keadaan lingkungan. Gejala-gejala yang timbul diatas membutuhkan suatu upaya, atau langkah-langkah yang baik guna menimalisir dampak yang berkelanjutan dan upaya atau langkah-langkah yang baik guna menimalisir dampak yang berkelanjutan. Upaya yang ada dapat diupayakan sesuai dengan kebutuhan, keinginan dan tugas perkembangan calon jamaah haji. Hal ini dilakukan dengan upaya bimbingan konseling yang dilakukan di KBIH Attaqwa dengan pembimbing. Pada dasarnya bimbingan merupakan pemberian bantuan yang bersumber pada kehidupan manusia yaitu untuk mengadakan suatu perbaikan dalam persoalan atau problem yang silih berganti.

Jadi peneliti dapat menyimpulkan bahwasannya Peran bimbingan konseling sangatlah penting dalam memberikan pemahaman seputar psikologis tentang kecamasan kepada calon jamaah haji yang hendak melaksanakan ibadah tersebut, untuk mengoptimalkan bimbingan manasik haji kepada calon jam'ah, tentunya dibutuhkan peran bimbingan konseling untuk di gunakan oleh para pembimbing, dalam hal ini penulis menganalisa mengenai peran bimbingan psikologis dalam mengoptimalisasikan bimbingan manasik haji pada calon jemaah haji di KBIH Attaqwa KH. Noer Alie. Untuk mencapai keberhasilan bimbingan konseling dalam mengurangi kecemasan terhadap calon jamaah haj manasik haji maka dibutuhkan peran bimbingan konseling dalam mengurangi kecemasan terhadap calon jamaah haji. DHaji pada hakekatnya merupakan aktifitas suci yang diwajibkan olehAllah kepada seluruh ummat islam yang telah mencapai (istitho'ah) mampu, disebut aktifitas suci karena seluruh rangkaian kegiatan adalah ibadah. Haji juga disebut sebagai ibadah puncak yang melambangkan ketaatan serta penyerahan diri secara total kepada Allah baik secara fisik-mental maupun spiritual

Menurut KH. M. Amien Noer yang disampaikan pada seminar haji (tanggal: 13 Februari 2018) "Mampu" atau "Istitho'ah bidang kesehatan adalah mampu menunaikan ibadah haji ditinjau dari jasmani yang sehat dan kuat agar dapat melaksanakan perjalanan dan mudah melakukan proses ibadah haji, berkala sehat dan memeiliki kesiapan mental untuk menunaikan ibadah haji di arab Saudi, serta aman bagi keluarga (Lukman hakim saifudin)

Sebelum berangkat ketanah suci, calon jema'ah haji di haruskan untuk mempersiapkan segala sesuatunya baik materi, fisik, mental serta yang tak kalah pentingnnya adalah pengetahuan seputar haji yang biasaanya disebut dengan manasik haji. Perjalanan ibadah haji adalah perjalanan yang suci, disamping memerlukan biaya yang tidak sedikit, juga memerlukan kesiapan fisik dan mental 
serta pengetahauan tentang haji.

Namun faktanya peneliti menemukan fenomena dilapangan terdapat beberapa peristiwa calon jema'ah haji mengalami gangguan mental seperti: Pertama disebabkan psikologis seperti jauh dari keluarga dalam jangka waktu yang lama. Kedua di sebabkan rasa kehawatiran yang tinggi.Ketiga di sebabkan gangguan perasaan oleh terganggunya kesehatan mental yaitu kecemasan Keempat di sebabkan stress ringan akibat aghorophobia ialah takut melihat orang banyak.

Menurut hasil wawancara dengan Ustd Fauzi (tanggal: 1 january 2018) jumlah calon jemaah haji yang mengikuti bimbingan manasik haji pada tahun 2013 ada 100 calon jema'ah haji yang mengikuti proses bimbingan manasik haji namun dari 100 calon jema'ah haji ada 3 calon jema'ah haji yang mengalami gangguan psikologis karena rasa kecemasan dan kehawatiran yang sangat tinggi disebabkan jauh dari keluarga dengan jangka waktu yang lama. Dan takut ketika disana mereka tidak bisa bersosialisi dengan masyarakat diarab Saudi.

Gangguan perasaan yang disebabkan oleh terganggunya kesehatan mental diantaranya adalah kecemasan dimana kecemasan adalah menifestasi dari berbagai proses emosi yang bercampur baur yang terjadi ketika orang sedang mengalami tekanan perasaan (frustaasi) dan pertentangan batin (konflik).

Kecemasan itu mempunyai segi yang didasari rasa takut, terkejut dan tidak berdaya, rasa berdosa/bersalah, terancam dan sebagainya juga ada segi yang terjadi diluar kesadaran dan tidak bias menghindari perasaan yang tidak menyenangkan itu. Rasa cemas itu terdapat dalam semuah gangguan jiwa dan ada bermacam-macam.

Menurut Zakiah Dardjat dalam bukunya kesehatan mental (2001: 8-9) menjelaskan bahwa keadaan yang tidak menyenangkan itu tidak terbatas kepada golongan tertentu saja, tetapi tergantung kepada cara orang mengahadapi sesuatu persoalan. Misalnya ada orang miskin yang gelisa karena banyak keinginannya yang tidak tercapai bahkan kebutuhan pokok saja idak bias dipenuhi. Sebaliknya ada pula orang kaya yang juga gelisah, cemas dan merasa tidak tentram dalam hidupnya tetapi sebab kecemasannya lain, bukan karena kekurangan uang melainkan oleh hal-hal lain seperti kebosanan, tidak tahu apa yang harus dilakukan uang banyak segalanya cukup. Atau pula ingin selalu menambah hartanya lebih banyak lagi.

Dalam situasi tertentu kadang-kadang calon jamaah haji dihadapkan pada suatu kesulitan yang bersumber dari dalam dirinya. Masalah-masalah ini timbul karena calon jamaah haji merasa kurang berhasil dalam menghadapi dan menyesuaikan diri dengan hal-hal dari dalam dirinya sendiri. Misalnya konflik 
dengan keluarga, krabat dan lain sebagainya dan gejala-gejala psikologis seperti prustasi, stress ringan merupakan sumber timbulnya masalah-masalah pribadi.

Masalah-masalah diatas ini sering dialami oleh para calon jamaah haji sebelum berangkat ketanah suci pada masa lansia yang ditandai penurunan kodisi fisiologis, psikologis karna sisebabkan kecemasan

maupun mental dapat disimpulkan bahwa pada masa lansia masalah pribadi ini timbul karena individu tidak tau kurang berhasil dalam mempertemukan antara aspek-aspek pribadi disatu pihak dan keadaan lingkungan.

Gejala-gejala yang timbul diatas membutuhkan suatu upaya, atau langkahlangkah yang baik guna menimalisir dampak yang berkelanjutan dan upaya atau langkah-langkah yang baik guna menimalisir dampak yang berkelanjutan. Upaya yang ada dapat diupayakan sesuai dengan kebutuhan, keinginan dan tugas perkembangan calon jamaah haji. Hal ini dilakukan dengan upaya bimbingan konseling yang dilakukan di KBIH Attaqwa dengan pembimbing. Pada dasarnya bimbingan merupakan pemberian bantuan yang bersumber pada kehidupan manusia yaitu untuk mengadakan suatu perbaikan dalam persoalan atau problem yang silih berganti.

Menurut Samsul Munir (2013: 23) Bimbingan konseling Islam proses pemberi bantuan terarah kontinu dan sistematis kepada setiap individu agar ia dapat mengembangkan potensi atau fitrah beragama yang dimilikinya secara optimal dengan cara menginternalisasikan nilai-nilai yang terkandung di dalam alqur'an dan hadis Rasulullah saw kedalam dirinya, sehingga ia dapat hidup selaras dan sesuai dengan tuntunan al-qur'an dan hadist. Apabila internalisasi nilai-nilai yang terkandung dalam al-qur'an dan hadist telah tercapai dan fitrah keberagamaan itu telah berkembang secara optimal maka individu tersebut dapat menciptakan hubungan yang baik dengan allah, dengan manusia dan alam semesta sebagai menifestasi dari peranannya sebagai khalifah dimuka bumi yang sekaligus juga berfungsi untuk mengabdi kepada allah. Dengan demikian bimbingan di bidang agama islam merupakan kegiatan dari dakwah islamiah. Karna dakwah yang terarah ialah memberikan bimbingan kepada umat islam untuk betul0betul mencapai dan melaksanakan keseimbangan hidup fid dunya wal akhirah.

Penelitian terdahulu berkaitan dengan konseling individual antara sebagai berikut: Penelitian Setyaningrum, Dewi, Setiawati, Denok (2013). Berjudul Pengaruh Persepsi Siswa Tentang Layanan Konseling Individu dan Persepsi Siswa Tentang Kompetensi Kepribadian Konselor Terhadap Minat Memanfaatkan Layanan Bimbingan dan Konseling. Penelitian Wardiah, W. (2018) berjudul Optimalisasi Layanan Bimbingan Kelompok Dan Konseling Individu dengan Menggunakan Media Power Point Sebagai Upaya Peningkatan Kebiasaan Belajar Siswa. Penelitian Fadhilah, Siti S., Hananto, Ipung. (2014) 
berjudul Keefektifan Bimbingan Kelompok Dengan Teknik Diskusi Untuk Mengubah Sikap Terhadap Layanan Konseling Individual Jurnal Counselium 1 (3). Penelitian Sumarto, S. (2015). Berjudul Evaluasi Hasil Program Layanan Bimbingan dan Konseling Individual di Sekolah Dan Madrasah.

Penelitian penelitian tersebut seting nya adalah sekolah dan sarannya siswa, sedangkan penelitian penulis setingnya perguruan tinggi dan sasarannya adalah Jemaah haji.

Jadi peneliti dapat menyimpulkan bahwasannya Peran bimbingan konseling sangatlah penting dalam memberikan pemahaman seputar psikologis tentang kecamasan kepada calon jamaah haji yang hendak melaksanakan ibadah tersebut, untuk mengoptimalkan bimbingan manasik haji kepada calon jam'ah, tentunya dibutuhkan peran bimbingan konseling untuk di gunakan oleh para pembimbing, dalam hal ini penulis menganalisa mengenai peran bimbingan psikologis dalam mengoptimalisasikan bimbingan manasik haji pada calon jemaah haji di KBIH Attaqwa KH. Noer Alie. Untuk mencapai keberhasilan bimbingan konseling dalam mengurangi kecemasan terhadap calon jamaah haj manasik haji maka dibutuhkan peran bimbingan konseling dalam mengurangi kecemasan terhadap calon jamaah haji. Dengan adanya bimbingan konseling maka pembimbing dan calo jamaah haji akan lebih mudah dalam mencapai suatu tujuan bimbingan manasik haji.engan adanya bimbingan konseling maka pembimbing dan calo jamaah haji akan lebih mudah dalam mencapai suatu tujuan bimbingan manasik haji.

\section{LANDASAN TEORITIS}

Teori yang diajadikan landasan teori dalam penelitian ini adalah teori bimbingan konseling dan kecemasan, Bimbingan dan konseling berkenaan dengan perilaku, oleh sebab itu tujuan bimbingan dan konseling adalah dalam rangka: pertama. Membantu mengembangkan kualitas kepribadian individu yang dibimbing atau dikonseling. Kedua, membantu mengembangkan kualitas kesehatan mental klien. Ketiga, membantu mengembangkan perilaku yang lebih efektif pada diri individu dan lingkungannya. Keempat, membantu klien menanggulangi problema hidup dan kehidupannya secara mandiri. Mengutip dari (Hamdan Bakran Adz Dzky 2004:7)

Bimbingan konseling merupakan salah satu bimbingan bidang pelayanan yang perlu dilaksanakan di dalam program pendidikan. Kebutuhan pelaksanaan bimbingan konseling berlatar belakang beberapa aspek diantaranya: 1) aspek psikologis. 2) aspek sosiologis. 3) aspek kultur. 4) aspek pedagogis. Dalam aspek psikologis siswa sebagai subyek didik merupakan pribadi yang unik dengan segala karakteristik perkembangannya dan memiliki kebutuhan serta dinamika 
dalam interaksinya dalam lingkungan. Sebagai pribadi yang unik terdapat perbeda'an individual antara siswa yang satu dan siswa yang lainnya. (Hamdani : 2012)

Bimbingan konseling adalah suatu proses pemberian bantuan yang terusmenerus dan sistematis kepada individu dalam memecahkan masalah yang dihadapinya. Agar tercapai kemampuan untuk memahami dirinya "self understanding" kemampuan untuk menerima dirinya "self acceptance" kemampuan untuk mengarahkan dirinya "self direction" dan kemampuan untuk merealisasikan dirinya "self realization" sesuai dengan potensi atau kemampuannya dalam mencapai penyesuaian diri dengan lingkungan, baik keluarga, sekolah, maupun masyarakat. (Jumhur dan Moh surya : 2012)

Konseling adalah sebuah profesi untuk penanganan masalah konseli yang berada dalam tekanan atau dalam kebingungan, yang berhasrat berdiskusi dan memecahkan semua itu dalam sebuah hubungan yang lebih terkontrol dan lebih pribadi dibandingkan pertemanan, dan mungkin lebih simpatik/tidak memberikan cap tertentu dibandingkan dengan hubungan pertolongan dalam praktikmedis tradisional atausetting psikiatrikMenurut Feltham dan Dryden(1993:2)

Pendekatan Konseling (counceling Aproach) disebut juga teori konseling, merupakan dasar bagi suatu praktek konseling. Pendekatan itu dirasakan penting karena jika dapat dipahami berbagai pendekatan atau teori-teori konseling, akan memudahkan dalam menentukan arah proses konseling. Akan tetapi untuk kondisi Indonesia memilih satu pendekatan / teori secara fanatic dan kaku adalah kurang bijaksana. Hal ini disebabkan satu teori konseling biasanya dilator belakangi oleh paham filsafat tertentu yang mungkin saja tidak sesuai dengan filsafat di Indonesia. (Jumhur dan Moh surya : 2012)

Berbagai definisi yang telah dikemukakan para ahli dapat disimpulkan bahwa bimbingan konselngn merupakan upaya untuk memberikan bantuan kepada individu atau siswa. Bantuan yang dimaksud adalah bantuan yang bersifat psikologis dan tercapainnya penyesuaian diri, perkembangan optimal dan kemandirian merupakan tujuan yang ingin dicapai dari pelaksanaan bimbingan.

Kecemasan adalah manifestasi dari berbagai proses emosi yang tercampur baur, yang terjadi ketiak oerang sedng mengalami tekenanan perasaan (frustasi) dan pertentangan batin (konflik). Sedangkan pendapat Sigmund Frued (1993: 81) sebagaimana dikutip supratiknya dalam buku psikologis perkembangan, kecemasan adalah suatu keadaan yang tegang yang ditimbulkan oleh factorfaktor dari luar bukan dari kondisi jaringan di dalam tubuh. (Zakiah Daradjat 2001: 27)

Kecemasan adalah suatu istilah yang menggambarkan gangguan psikologis yang dapat memiliki karakteristik yaitu berupa rasa takut, 
keprihatinan terhadap masa depan, kekhawatiran yang berkepanjangan, dan rasa gugup. Rasa cemas memang biasa dihadapi semua orang. Namun, rasa cemas disebut gangguan psikologis ketika rasa cemas menghalangi seseorang untuk menjalani kehidupan sehari-hari dan menjalani kegiatan produktif (Zakiah Daradjat 2001: 27)

Kecemasan adalah emosi tidak menyenangkan yang ditandai dengan istilah-istilah seperti khawatir dan rasa takut yang kadang-kadang kita alami dalam tingkah laku berbeda-beda. Maka demikian penulis dapat menarik kesimpulan bahwa kecemasan adalah kondisi emosional yang tidak menyedangkan yang ditandai oleh persaan-perasaan subjektif diantaranya seperti: 1) Ketegangan. 2) Ketakutan. 3) Kekhawatiran yang sangat tinggi dan ditandai dengan aktifnya sistem syaraf pusat. (Atikson 2003: 163)

Bahwa sesungguhnya pengearuh rasa cemasa yang paling buruk itu adalah kehancuran yang ditimbulkan pada kemampuan kita untuk berakal sehat. Apabila kita merasa cemas dan takut, pikiran kita akan melayang kesana kemari, berlompat tak menentu dan kita akan kehilangan kemampuan dalam membuat keputusan, bagaimanpun juga kalau kita berani memaksakan diri untuk mengahadapi akibat yang paling buruk dan secara mental kita memukulnya, kita akan dapat memperkecil imajinasi-imajinasi yang smpang siur dan menenmpatkan diri kita pasa suatu posisi diama kita akan dapat berkonsentrasi mengahadapi persoalan tersebut. (Mahfud An : 2003)

Penyebab pasti rasa cemas tidak diketahui. Namun, sudah terbukti bahwa rasa cemas disebabkan oleh kombinasi faktor-faktor tertentu. Seperti gangguan mental lainnya, rasa cemas disebabkan oleh gagalnya saraf-saraf otak untuk mengontrol emosi dan rasa takut. Contohnya stress dapat mengubah alur komunikasi sel-sel saraf dalam sirkuit otak. Hal ini akan mengubah struktur otak tertentu yang mengkontrol emosi. Struktur otak tertentu ini pada awalnya dibentuk dari genetik dan keturunan keluarga Faktor lingkungan seperti trauma masa kecil (contohnya kekerasan rumah tangga, kehilangan orang tua, dll) atau masalah besar dalam hidup (contohnya krisis finansial dan gagalnya hubungan asmara) dapat memicu kecemasan. Gejala-gejala kecemasan juga dapat disebabkan oleh gangguan sistemik seperti hipertiroidisme, masalah endokrin, gula darah rendah, kekurangan kalsium, dan penyakit jantung.Kecemasan atau mudah cemas bukan disebabkan oleh lemahnya kepribadian seseorang atau pendidikan yang buruk (Mahfud An: 2003)

Kecemasan merupakan respon individu terhadap suatu keadaan yang tidak menyenangkan dan dialami oleh semua makhluk hidup dalam kehidupan sehari-hari. Kecemasan merupakan pengalaman subjektif dari individu dan 
tidak dapat di observasi secara langsung serta merupakan suatu keadaan emosi tanpa objek yang spesifik. Kecemasan pada individu dapat memberikan motivasi untuk mencapai sesuatu dan merupakan sumber penting dalam usaha memelihara keseimbangan hidup. Kecemasan adalah respon emosi tanpa objek yang spesifik yang secara subjektif dialami dan di komunikasikan secara interpersonal (Suliswati 2005 : 50).

\section{HASIL DAN PEMBAHASAN}

Penelitian ini dilakukan di KBIH Attaqwa KH. Noer Alie Bekasi yang berada Jl. Raya KH. Noer Alie Ujungharapan Kelurahan Bahagian Kec. Babelan Kab. Bekasi Kode Pos 17612 No Tlpn (021) 891328 39. Alasannya adalah kerena topik yang dibahas dalam penelitian ini sangat penting untuk diketahui oleh siapa pun itu yang berkaitan dengan Peran Bimbingan Konseling Pada Calon Jema'ah Haji KBIH, hal ini penting terutama untuk aktifitas KBIH terserbut. Latar belakang berdirinya KBIH At-Taqwa ini tidak terlepas dari sejarah Yayansan At-Taqwa, yang mana pada waktu itu di Wilayan Babelan Bekasi banyak masyarakat yang awam masalah ibadah haji. Sedangkan jamaah haji itu sangat sulit untuk daftar haji, kerna banyak hal-hal yang berat salah satunya dalam materi maka dari itu ibadah haji sangatlah berharga terutama dalam lingkungan masyarakat Ujung Harapan Kab. Bekasi ini. Pada tahun $2006 \mathrm{KBIH}$ At-Taqwa didirikan oleh dibawah Yayasan At-Taqwa. Kemudian masyarakat khususnya Kab Bekasi ini banyak yang menggunakan jasa KBIH At-taqwa ini.

Kelompok Bimbingan Ibadah Haji (KBIH) Attaqwa yang berada dibawah naungan Yayasan Attaqwa masih bisa melanjutkan perjuangan dalam membantu masyarakat untuk bisa menunaikan ibadah haji ke Baitulloh. Sebagai wadah yang bergerak dalam bidang sosial kemasyarakatan dan demi keberlangsungan Kelompok Bimbingan Ibadah Haji KBIH At-Taqwa dipandang perlu legalitas dari Kantor Departemen Agama urusan Haji dan Umroh. KBIH Attaqwa KH. Noer Alie Bekasi sebagai tempat penelitian merupakan lembaga yang memiliki bimbingan psikologis dan mental baik dalam kualifikasinya, dibanding dengan lembaga yang ada di wilayah kota Bekasi, dari mulai rancangan program, pelaksanaan program, kemudian pembimbig yang lengkap serta kompeten di bidangnya, dan sarana dan prasarana haji yang sudah lengkap dan tersedia, demikian yang menjadi pertimbangan peneliti dalam menentukan tempat penelitian mengenai peran bimbingan kesiapan psikologis kepada calon jema'ah haji.

Data peneliti ini menggunakan metode, kualitatif deskriptif. Penelitian kualitatif deskriptif yaitu penelitian yang bertujuan untuk menggambarkan keadaan fenomena yang terjadi secara sistematik dan rasional.

Dalam metode penelitian ini, penulis bermaksud untuk dapat menggambarkan secara sistematik dan objektif mengenai proses bimbingan 
konseling dalam mengruangi kecemasan terhadap calon jamaah haji $\mathrm{KBIH}$ Attaqwa Ujung Harapan Bahagia Kab. Bekasi Pemilihan dengan metode deskritif ini yaitu dengan alasan agar penelitian lebih mendalam jika menggunkan pendekatan kualitatif.

Jenis data yang akan penulis kumpulkan dalam penelitian ini adalah data tentang proses bimbingan konseling dalam mengurangi kecemasan terhadap calon jamaah. Teknik bimbingan konseling yang digunakan dalam pelaksanaan manasik haji. Faktor pendorong dan penghambat dalam bimbingan konseling. Dan manfaat bimbingan konseling melalui bimbingan konseling dalam mengurangi kecemasan calon jamaah haji.

\section{Pertama Karakteristik calon jamaah haji}

Berdasarkan hasil penelitian di atas bahwa karakteristik calon jamaah haji dengan jumlah yang banyak sangat beragam ada yang perilakunya pendiam atau tertutup ada juga perilakunya senang berbicara ada juga yang perilakunya suka membantu orang lain ada juga yang pelupa dan sulit dalam berkonsentrasi bingingung ketika menerima materi yang disampaikan oleh pembimbing

Dalam teori kepribadian Buckhori (1982: 92) mengungkapkan bahwa kepribadian berarti integrasi dari seluru sifat seseorang baik sifat-sifat yang dipelajarinya maupun sifat-sifat yang diwarisinya yang menyebabkan kesan yang khas, unik pada orang lain. Memahami karakteristik kepribadian jamaah haji tidaklah mudah karna jamaah haji mempunyai karakter yang berbeda-beda sebab calon jamaah haji tidak semuah berlatar belakang pendidikan dan tidak semuahnya mapan (orang kaya) fakta yang sering terjadi ketika dilapangan jamaah mengalami rasa kehawairan yang sangat tinggi hingga pada akhirnya menimbulkan kecemasan. Cemas dan takut dapat menghantui orang yang kehilangan harta, jabatan dan kehilangan anggota keluarga ataupun sang kekasih. Contohnya misalkan seseorang mengumpulkan harta selama bertahun-tahun melalui perjuangan yang berat dan berliku, terkadang untung terkadang rugi, terkadang diatas terkadang diabawah, namun kemudian mencapai puncak keberhasilan. Hartanya berlimpah dan rezeqi dating bagaikan mata air yang tak pernah henti walaupun musim kemarau. Setiap ia mengayunkan cangkulnya ia menemukan emas berkilauan. Tetapi pada suatu ketika harta yang diperoleh itu hancur atau musnah tanpa ada yang tersisa, kecuali hanya pakaian yang melekat diabadan dalam keadaan demikian seseorang akan terserang perasaan cemas dan takut. Kedua cemas dan takut memikirkan masa kini kalau orang cemas dan takut memikirkan yang sekarang. Barang kali karna orang lain mendapat nikamat sedangkan ia tidak ata karna melarat tak punya harta barangkali pula karna citacitta dan keinginannya kandas di tengah jalan atau hari ini kedudukannnya menurun atau mungkin hari ini pekerjaannya menumpuk atau hari ini harus 
mengahadap kepada atasannya atau hari ini haru mengobatkan anaknnya yang sakit keras sementara ia tidak punya uang untuk itu? Banyak orang yang hari in dalam mengahadapi kehidupannya debgan penuh kecemasan dan ketakutan. Ketiga cemas dan takut menghadapi masa depan Banyak di antara manusia yang mencemaskan masa depannya ia memandang masa depannya dengan pandangan orang celaka, dengan meletakan kaca mata hitam kelam pada kedua matanya, masa denpan itu suram dan masa depan itu gelap. Disela-sela kaca mata itu dia melihat kehidupan orang-orang yang hidup, masa, juga tempat. Ia amat putus asa kehilangan kepercayaan terhadap hari esok dan kehilangan cita-cita untuk menggapai kebahagiaan, didalam dirinya telah tertanam pengertian bahwa segala urusan tidak berjalan dari keburukan, melainkan kepada yang lebih buruk dan tidak akan berjalan dari yang lebh buruk melainkan kepada yang lebih buruk.

Maka dapat disimpilkan oleh peneliti bahwa tugas pembimbing untuk memberikan bimbingan konseling pada calon jamaah haji sebelum pergi ke tanah suci dengan memberika pengetahuan yang luas, dengan cara menggunakan bimbingan kelompok, bimbingan tadzkirah serta konsultasi dan konseling sehingga calon jamaah lebih siap secara psikologis untuk melakukan ibadah haji ke tanah suci dengan niat yang benar untuk mendapatkan haji yang mabrur.

Di samping itu di dalam memberikan bimbingan dimaksudkan agar calon jamaah haji dapat mencapai kesejahteraan hidupnya sesuai petunjuk yang dikehendaki allah dan disinilah letak bimbingan sesungguhnya. Adapun metode yang digunakan dalam mengatasi kecemasan pada calon jamaah haji di $\mathrm{KBIH}$ Attaqwa meliputi yaitu : Pertama Bimbingan Kelompok Bimbingan kelompok merupakan salah satu bentuk layanan yang diberikan di KBIH Attaqwa dalam melakukan bimbingan ibadah haji karna ini merupakan bagian dari pola sarana untuk menunjang perkembangan optimal calon jamaah haji yang dihaarapkan dapat mengambil manfaat dari materi yang disampaikan pembimbing. Kedua Bimbingan Tadzkirah Bimbingan tadzkirah ini diberikan dalam bentuk ceramah yang berisi tentang nasehat, pencerahati dorongan dan motivasi keagamaan yang dilakukan oleh pembimbing pada jadwal bimbingan manasik haji. Berdasarkan proseskerjanya bimbingan tadzkirah ini dapat dilihat dari dua sisi yaitu sisi subtansi makna dan sisi penggunanya dalam teknik bimbingan konseling islam. Kata tadzkirah secara bahasa diambil dari kata dzakara yang dapat diartikan megingat atau menyebut sesuatu. Sedangkan secara istilah dzikir dapat bebartu: hadirnya suatu makna di dalam diri seseorang. Ketiga Konsultasi dan Konseling Konsultasi dan konseling ini diberikan kepada calon jamaah haji setelah pemberian bimbingan tadzkirah atau dalam keadaan keadaan tertentu yang membutuhkan berdasarkan kepada materi atau informasi yang didapat dari pembimbing dengan Tanya jawab kepada pembimbing. 


\section{Karakteristik Calon Jamaah Haji KBIH Attaqwa KH. Noer Alie Bekasi}

Untuk memperoleh data mengenai program peran bimbingan konseling dalam mengurangi kecemasan terhadap calon jamaah haji, maka penulis mengadakan wawancara dengan pembimbing dan calon jamaah haji di KBIH Attaqwa Bekasi.

Berdasarkan hasil wawancara dengan pembimbing KBIH Attaqwa Ustd Ahmad Fauzi pada (tanggal,5 Maret, 2018) bahwasannya jumlah calon jamaah haji tahun 2018 sekitar 214 dengan banyaknya calon jamaah maka karakteristiknyapun beragam ada yang karakteristinya pendiam atau tertutup ada juga yang karakter jamaah yang senang berbicara dan susah dihentikan ada juga yang karakternya suka menolong orang lain ada juga yang sedikit agak pelupa, sulit berkosentrasi dan pada akhirnya bingung ketika dia ditanya tentang materi yang disampaikan oleh pembimbing dan banyak yang lainnya.

Berdasarkan hasil observasi peneliti dilapangan pada (tanggal,8 April, 2018) bahwasannya karakteristik calon jamaah haji di KBIH Attaqwa sangat beragam dan unik karna dari latar belakangnya pun jelas berbeda ada yang Cenderung diam dan kalem dan ada juga yang Mudah bergaul, santai, tenang dan teguh ada juga yang mudah marah, suka mengeluh karna mungkin faktor usia dan ada juga dalam mengikuti bimbingan susah dalam memahami materi yang disampaikan oleh pembimbing ada juga diantara mereka cenderung ingin dikenal dan disenagi orang lain.

Sebagaimana diperkuatkan oleh pernyataan Menteri Agama Lukman Hakim Saifuddin menjelaskan (tanggal. 26, januari, 2016) ada karakteristik khas jemaah haji Indonesia. Di antaranya, tidak punya pengalaman bepergian, baik ke luar negeri maupun ke luar kota." Tipologi atau karakteristik jemaah kita itu khas, yaitu sebagian besar dari mereka belum pernah berhaji, belum pernah ke luar negeri, bahkan ke luar dari kabupaten atau kotanya saja belum pernah," kata Lukman. Di sisi lain, ada sebagian jemaah haji yang Indonesia telah beberapa kali bepergian ke luar negeri, bahkan hampir setiap hari. Ini menciptakan kesenjangan yang cukup tinggi." Saya ingin menggambarkan disparitas, kesenjangan itu. Dari yang menguasai bahasa Inggris sampai yang berbahasa Indonesia pun tidak bisa,(Dream.co.id) "Kesenjangan sosial adalah suatu keadaan dimana terjadi ketidakseimbangan sosial atau ketimpangan sosial dalam masyarakat yang menjadikan suatu perbedaan yang sangat mencolok antar masyarakat. kesenjangan sosial ditandai dengan adanya peluang dan manfaat yang tidak sama untuk posisi sosial yang berbeda dalam suatu status atau kelompok masyarakat. Kesenjangan sosial dapat dilihat dari tidak samanya proporsi barang atau jasa, imbalan, kekayaan, kesempatan dan hukuman yang didapatkan antar masyarakat. 
Selain itu, tambah Lukman, karakteristik jemaah haji Indonesia yang lain yaitu faktor usia, fisiologis,psikologis Sebagian besar jemaah haji Indonesia berusia di atas 51 tahun serta kondisi fisologis dan psikologisnya sangat menurunBerdasarkan data, kata dia, jumlah jemaah usia di atas 51 tahun mencapai 61,3 persen pada musim haji 2016. Pada usia tersebut, jemaah haji rentan mengalami gangguan fisologisnya dan mental Yang berisiko tinggi dari sisi kesehatan tidak kurang 66,97 persen, Permasalahan lain, jemaah haji Indonesia ternyata punya tingkat kelelahan yang tinggi. Penyebabnya, mereka harus menjalani pelbagai kebiasaan masyarakat sebelum berangkat haji. Karena sebelum berangkat ada selamatan. Dan itu terus menerus,Karakteristik ini harus disadari oleh semua pihak yang terlibat dalam penyelenggaraan ibadah haji. Sehingga, Lukman cukup menyangsikan ibadah haji dapat berjalan efektif jika diselenggarakan oleh badan tertentu yang notabene terpisah dari pemerintah."Saya tidak bisa membayangkan kalau (penyelenggaraan) haji dilakukan oleh badan tersendiri, Karakteristik ini harus disadari oleh semua pihak yang terlibat dalam penyelenggaraan ibadah haji. Sehingga, Lukman cukup menyangsikan ibadah haji dapat berjalan efektif jika diselenggarakan oleh badan tertentu yang notabene terpisah dari pemerintah.

Demikianlah karakteristik calon jamaah haji yang di kemukakan di atas dapat disimpulkan bahwa prilaku dan kemampuan maupun hasil dari pembawaan lingkungan social, sehingga menetukan pola aktivitas dalam menjalankan ibadah haji. jamaah mempunyai karakteristik yang dapat di bedakan dengan yang lainnya karakteristik tersebut yaitu

Pertama Karakteristik fisik Perkembangan fisik pada masa lansia terlihat pada perubahan perubahan fisiologis yang bisa dikatakan mengalami kemunduran, perubahan perubahan biologis yang dialami pada masa lansia yang terlihat adanya kemunduran tersebut sangat berpengaruh terhadap kondisi kesehatan dan terhadap kondisi psikologis. Perubahan ini juga terjadi pada aspek psikologi dan sosialnya. Selain itu permasalahan mengenai kemampuan motorik juga perlu untuk dibahas secara terperinci hal ini terlihat dari data calon jamaah haji yang di temui dilapangan pada tanggal (8, april, 2018)

Kedua Karakteristik PsikisKondisi psikisnya stabil atau mengalami gangguan.Gangguan yang menghasilkan pribadi agak pembimbang, atau agak impulsif, maka ketergangguan itu dipandang biasa saja. Tapi perlu diungkapkan dalam ciri gerak fisik, seperti sering mengedipkan mata, atau sering menghapus tangannya dengan saputangan karena telapak tangannya selalu basah, atau cepat menjadi gagap. Terutama kalau dia sedang menghadapi ketegangan. Memasukkan gerakan-gerakan tidak lazim sebagai gambaran psikis yang dialami pelaku cerita, maksudnya adalah yang pernah mengalami goncangan psikis yang amat kuat, yang sangat tidak enak, yang memberikan bekas sangat dalam pada kondisi psikisnya. Dia menjadi terlalu perasa, gampang tersinggung. Mungkin 
juga gampang meledak. Namun dalam keadaan tenang, dia adalah manusia normal biasa. (fakta dilapangan)

Karakteristik kepribadian sebagai pengorganisasi yang dinamis dari system psikofisik yang menentukan penyusuaian diri dengan lingkungannya (Robbin $1986: 12)$

\section{Peran Bimbingan Konseling Dalam Mengurangi Kecemasan Calon Jamaah Haji KBIH Attaqwa KH. Noer Alie Bekasi}

Berdasarkan hasil wawancara dilapangan dengan Ustd Nur Amien ketua KBIH Attqwa Ujung Harapan Bekasi pada (tanggal: 8 April 2018) bahawa Dalam proses bimbingan ibadah haji, seseorang tidak akan terlepas dari suatu masalah, baik masalah yang bersifat fisik, psikis, keluarga, sosial, religius dan lain-lain. Masalah-masalah ini pasti menuntut adanya penyelesaian, tetapi tidak semua masalah bisa diselesaikan oleh individu yang mempunyai masalah itu sendiri, melainkan individu tersebut membutuhkan seseorang yang dianggap mampu untuk mengarahkan individu yang mempunyai masalah agar dapat keluar dari masalah tersebut. Sebenarnya individu memiliki potensi yang unik untuk berpikir rasional dan irrasional. Individu yang sehat merupakan individu yang bisa berpikir rasional sehingga ia dapat menyelesaikan masalahnya dengan cara yang tepat.

Berdasarkan hasil observasi (tanggal,8,April,2018) diketahui bahwa proses bimbingan konseling dalam mengurangi kecemasan tcalon jamaah haji di KBI Attaqwa Bekasi pada pelaksanaan proses terdapat beberapa unsur bimbingan didalamnya meliputi yaitu : Pertama Pembimbing Pembimbing sebagai pelaku dakwah yang mempunyai kewajiban untuk mengajak calon jamaah haji untuk selalu berbuat baik dan mendekatkan diri kepada allah agar calon jamaah haji merasa tenang baik secara jasmani dan rohani sehingga tidak ada rasa khawatir atau cemas sehingga menimbulkan kesiapan psikologis yang bagus pada calon jamaah Keberhasilan pelaksanaan bimbingan untuk mengurangi kecemasan tentunya dipengaruhi oleh kepibadian diri calon jamaah hajii dan tauladan yang profesional dari seorang pembimbing. Pembimbing harus memiliki karakteristik yang dilihat dari sifat nafsiyah, yaitu kepribadian yang sempurna secara lahir dan batin yang mencerminkan perilaku keislaman.

Pembimbing dalam kegiatan ini yaitu KH. Mummad Natsir dkk selaku pembimbing di KBIH Attaqwa. Beliau selalu hadir untuk acara tersebut walau dalam keadaan sibuk apapun, kecuali apabila ada halangan yang sangat serius yang benar-benar tidak bisa ia tinggalkan. 
Bimbingan konseling islam proses pemberi bantuan terarah kontinu dan sistematis kepada setiap individu agar ia dapat mengembangkan potensi atau fitrah beragama yang dimilikinya secara optimal dengan cara menginternalisasikan nilai-nilai yang terkandung di dalam al-qur'an dan hadis rasulullah saw kedalam dirinya, sehingga ia dapat hidup selaras dan sesuai dengan tuntunan al-qur'an dan hadistKondisi Calon Jamaah Haji Setelah Mendapatkan Bimbingan Konseling (Samsul Munir 2013:23). Kedua jamaah Para calon jamaah haji dalam proses bimbingan mental dalam mengurangi kecamasan ini berperan sebagai orang yang dibimbing atau terbimbing. Dalam hal ini, mereka harus mengikuti semua kegiatan bimbingan yang dipimpin oleh pembimbing dengan memerhatikan materi, mengikuti bacaan dzikir kegiatan ini tidak dibatasi oleh usia, profesi atau pendidikan. Semua orang bisa mengikuti kegiatan ini asal mempunyai niat yang baik dan berkomitmen dengan kesungguhan agar jasmani dan rohani calon jamaah haji siap untuk melakukan ibadah haji ke tanah suci.

Berdasarkan data yang didapatkan bahwa jumlah calon jamaah haji di KBIH Attaqwa Bekasi pesantren 214 orang. Dalam kegiatan bimbingan terkadang ada beberapa calon jamaah yang tidak dapat mengikutinya dengan alasan ada kegiatan lain di luar yang sifatnya lebih penting. Ketiga materi adapun materi yang di sampaikan yaitu: Pertama materi tentang psikologi haji Materi psikologi haji ini berkenaan dengan sisi psikologi seseorang, psikologi adalah ilmu tentang kejiwaan, mental ddan perilaku jadi materi psikologi adalah yang berhubungan dengan kejiwaan dan perilaku calon jamaaah haji. Kedua materi kesehatan mental Materi kesehatan mental yang diberikan oleh pembimbing kepada clon jamaah haji adala materi yang bersifat pencegahaan agar calon jamaah haji dapat beradaptasi dengan lingkungan luas, serta agar calon jamah haji tidak mendapatkan gangguan-gangguan, perasaan mudah curiga, perasaan gagal, perasaan kecemasan dan perasaan negative lainnya. Ketiga motivasi haji Materi ini guna untuk membangkitkan dan memelihara motivasi untuk menunaikan ibadah haji agar calon jamaah haji tetap bersemangat dalam melakasanakan ibadah haji. Keempat membaca yasin dan ratibul hadad Calon jamaah haji diwajibkan membaca yasin dn ratib diawal pembukaan bimbingan agar mendapatkan ketenangan dan mendapatkan ridho dari Allah Swt, Matei-materi ini disusun oleh pembimbing secara berurutan

Adapun metode yang digunakan dalam mengatassi kecemasan calon jamaah haji ada berbagai macam yaitu : Pertama Bimbingan Kelompok Berdasarkan hasil pengamatan peneliti dilapangan tentang kondisi bimbingan kemlompok dilapangan pada (tanggal,8,april,2018) bahwasannya kondisi dilapangan menunjukan adanya bahwa layanan biimbingan kelompok semakin menjadi kegiatan rutinitas dalam melakukan penyelenggaraan program bimbingan haji kondisi ini terjadi karna layanan bimbingan kelompok memiliki beberapa unggulan diantaranya yaitu: 1) memfasilitasi calon jamaah haji yang 
lebih berani berbicara dan terbuka saat bersama-sama temannya yang lain . 2) dapat melayani sejumlah calon jamaah haji dalam waktu yang bersamaan, membangun susasana saling percaya, menimbulkan keakraban, saling membantu dan empati diantara sesama anggota

Bimbingan kelompok merupakan salah satu bentuk layanan yang diberikan di KBIH Attaqwa dalam melakukan bimbingan ibadah haji karna ini merupakan bagian dari pola sarana untuk menunjang perkembangan optimal calon jamaah haji yang dihaarapkan dapat mengambil manfaat dari materi yang disampaikan pembimbing.

dalam buku bimbingan konseling kelompok yang ditulis oleh lilis satriah bahwa layanan bimbingan kelompok dimaksudkan untuk memungkinkan seseorang secara bersama-sama memperoleh berbagai bahan dari nara sumber (terutama pembimbing) yang bermanfaat untuk kehidupan sehari-hari baik sebagai individu maupun sebagai pelajar. (Sukardi 2005: 48)

Pendapat lain mengatakan mengatakan bimbingan kelompok adalah suatu kegiatan kelompok, diamana pimpinan kelompok menyediakan onformasiinformasi dan mengarahkan diskusi agar anggota kelompok menjadi lebih social untuk membantu anggota-anggota kelompok dalam mencapai tujuan bersama. menurut (Wibowo 2005: 17)

Berdasarkan pendapat diatas oleh para ahli peneliti dapat menyimpulkan bahwasannya bimbingan kelompok dipandu oleh pemimpin kelompok atau nara sumber yang menyediakan informasi berupa materi yang bermanfaat untuk dapat membantu meningkatkn pengetahuan dan ketrampilan.

Kedua bimbingan tadzkirah Berdasarkan hasil pengamatan peneliti dilapangan bahwasannya kondisi bimbingan tadzkirah yang dilakukan oleh pembimbing pada saat dilapangan menunjukan bahwa bimbingan tadzkirah ini sangat lebih membantu dan efektif karna calon jamaah haji ketika dieberikan bimbingan tadzkirah calon jamaah haji lebih tanang dan lebih aktif dalam bertanya sesuatu yang diatidak ketahui bimbingan ini diberikan kepada calon jamaah haji oleh pembimbing dalam bentuk tausiah yang didalamnya berisi tentang naseha-nasehat yang sesuai ajaran agama islam dan motivasi

Marlina (2012: 253) menurutnya motivasi bagi remaja tidak bisa dilakukan dengan cara paksa melainkan dengan cara memberikan perhatian ekstra. Rahim (2006: 85) mendefinisikan motivasi sebagai suatu tenaga atau faktor yang terdapat dalam diri manusia yang menimbulkan, mengarahkan dan mengorganisasikan tingkah laku seseorang.

Bimbingan tadzkirah ini diberikan dalam bentuk ceramah yang berisi 
tentang nasehat, pencerahati dorongan dan motivasi keagamaan yang dilakukan oleh pembimbing pada jadwal bimbingan manasik haji.

Berdasarkan proseskerjanya menurut Isep Zaenal Arifin dalam bukunya bimbingan dan perwat rohani islam mengatakan bimbingan tadzkirah ini dapat dilihat dari dua sisi yaitu sisi subtansi makna dan sisi penggunanya dalam teknik bimbingan konseling islam. Kata tadzkirah secara bahasa diambil dari kata dzakara yang dapat diartikan megingat atau menyebut sesuatu. Sedangkan secara istilah dzikir dapat bebartu: hadirnya suatu makna di dalam diri seseorang. (Isep Zainal Arifin 2015: 138)

tadzkirah dapat mengandung makna peringatan dan pelajaran, kata ini disebut didalam al-qur'an sebanyak Sembilan kali dalam tujuh surat.

Karna kata tadzkirah mengandung makna pelajaran sering kali dipakai dan dipertukarkan dengan kata nasehat dalam bahasa Indonesia, hal ini menggambarkan bahwa memang aktivitas bimbingan tadzkirah yang digunakan dalam bimbingan manasik haji tidak lain bimbingan melalui pemberian ceramah, nasehat yang berisi tentang keagamaan, motivasi dan lain sebagainya. (M. Quraish Shihab 1997: 346-347)

Ketiga Konsultasi dan konseling Berdasarkan hasil pengamatan peneliti dilapangan tentang kondisi konsultasi dan konseling yang dilakukan oleh pembimbing sangat efekif namun konsultasi dan konseling ini waktunya tida ditentukan konsultasi dan konseling ini bias dilakukan kapan saja karna program ini dilakukan di kantor KBIH lansgung jadi ketika calon jamaah haji membutuhkan konsultasi atau konseling tinggal dating langsung kekantor KBIH dan bias juga di kediaman pembimbing.

Konsultasi dan konseling ini diberikan kepada calon jamaah haji setelah pemberian bimbingan tadzkirah atau dalam keadaan keadaan tertentu yang membutuhkan berdasarkan kepada materi atau informasi yang didapat dari pembimbing dengan Tanya jawab kepada pembimbing.

Dalam buku bimbingan sumber data terbarudan perawatan rohan islam mengatakan konsultasi adalah pembicaraan biasa yang berisi Tanya jawab atau dapat berarti pertukaran pikiran untuk mendapat petunjuk atau pertimbngan, baik berupa kesimpulan, nasihat atau saran yang sebaik-baiknya dalam memecahkan masalah atau memutskan sesuatu. Menurut Isep Zaenal (Arifin 2015: 141)

Pendapat lain konseling adalah seluruh upaya bantuan yang diberikan konselor kepada konseli supaya dia memperoleh konsep diri dan kepercayaan diri sendiri, untuk dimanfaatkan olehnya dalam memperbaiki tingkah lakunya pada masa yang akan datang. Sedangkan konseling untuk calon jamaah haji memang tidak dilakukan secara intensif dan berkala tetapi bias dilakukan dalam 
pertemuan-pertemuan seperti mentoring atau kekantor $\mathrm{KBIH}$ secara langsung. Natawijaya (1987: 5).

Berdasarkan pendapat beberapa para ahli di atas, Maka peneliti dapat menyimpulkan bahwa konsultasi dan konseling merupakan suatu upaya bantuan yang dilakukan dengan tatap muka antara konselor dan calon jamaah yang berisi usaha yang laras yang dilakukan dalam suasana keahlian yang didasari atas norma-norma yang berlaku, agar calon jamaah haji memperoleh konsep kepercayaan diri sendiri.

\section{Kondisi Calon Jamaah Haji Setelah Mendapatkan Bimbingan Konseling Dalam Mengurangi Kecemasan Calon Jamaah Haji}

Untuk mengetahui gambaran setelah mendapatkan bimbingan konseling dalam mengurangi kecemasan terhadap calon jamaah haji peneliti menggunakan metode wawancara kepada calon jamaah haji yang sudah mendapatkan bimbingan dilpangan diataranya: Pertama beradasarkan hasil wawancara Ahmad Fauzi (tgl: 05/03/18) Alhamdulillah, setelah diadakan bimbingan mental untuk mengurangi gejala kehawatiran atau kecemasan pada calon jamaah haji sebelum berangkat ke tanah suci jamaah haji lebih siap dari sebelumnnya karna mereka kita bimbing terus sampai semuahnya siap. Kedua berdasarkan hasil wawancara Ahmad Ustuchri Ibmi (tgl: 8/04/18) Alhamdulillah, saya pribadi sangat senang sekali ketika di KBIH Attaqwa ini ada program bimbingan mentalnya karna menurut saya pergi haji itu bukan hanya siap secara materi tapi dari segi jasmani dan rohaninnyapun harus siap jadi sebabyang saya ketahui bahwa di KBIH itu biasanya hanya mendapatkan bimbingan secara umum saja tidak mendaptkan bimbingan khusus jadi pada intinya saya pribadi jadi percaya diri dengan adanya bimbingan dalam mengurangi kecemasan ini. Ketiga Berdasarkan hasil wawancara dengan Ibu Amih pada (tgl: 8/04/18 alhamdulillah saya sangat bersyukur sekali dan bertrimakasi kepada pembimbing yang sudah memberikan bimbingan untuk megurangi rasa cemas pada diri saya sehingga saya merasa lebih tenang dan nyaman untuk melakukan proses ibadah haji.

Maka Dapat disimpulkan oleh peneliti bahwa terdapat perbedaan yang signifikan tingkat kecemasan sebelum dan sesudah menerima bimbingan konseling pada kelompok calon jamaah haji dalam mengurangi kecemasan terhadap calon jamaah haji dengan pernyataan ini seperti yang ditunjukan hasil penelitian menggunakan metode wawancara bahwa bimbingan konseling efektif dan dibutuhkan karna dapat menurunkan kecemasan pada calon jamaah haji.

\section{PENUTUP}

Berdasarkan penelitian diatas maka dapat disimpulkan sebagai berikut: 
Pertama hampir seluruh calon jamaah haji di KBIH Attaqwa Bekasi mengalami masalah-masalah psikologis dan sosiologis yaitu : (a). kurangnya pengetahuan tentang pelaksanaan ibadah haji b). Rasa takut ketika melihat orang banyak (aghorophobia) c). perasaan cemas yang berlebihan d). cuaca yang berbeda dengan tempat tinggalnya e).

Kedua KBIH Attaqwa Bekasi dalam mengatasi masalah-masalah yang dihadapi maupun oleh jamaahnya maka dilakukan kegiatan bimbingan konseling melalui metode : a). Bimbingan kelompok b). Bimbingan tadzkirah c). Konsultasi dan konseling

Ketiga Setelah dilakukan pendekatan bimbingan konseling hasilnya adalah para calon jamaah mengalami perubahan pada aspek kognitif yaitu pemahamannya meningkat dan pengetahuannya bertambah. Adapun aspek efektifnya terutama pada rasa kehawatirannya semakin berkurang. Demikian pula dalam aspek fisik dan ketrampilan jamaah semakin siap untuk melakukan ibadah haji.

Berdasarkan temuan-temuan penelitian di atas, maka penulis dapat menyampaikan saran sebagai berikut pertama, pembimbing sebaiknya lebih memiliki keyakinan bahwa segala sesuatu yang dilakukan pasti memberikan keberhsilan, salah satu cara yang biasa ditempuh adalah melaksanakan layanan bimbingan konseling dengan standard dan prosedur oprasional yang benar dalam melaksanakan bimbingan. Kedua, ketua KBIH sebaiknya memberikan perhatian terhadap fasilitas dan kesempatan kepada pembimbing dalam melaksanakan bimbingan konseling. Agar lebih ditingkatkan lagi program bimbingan haji dan umrah supaya program yang diberikan KBIH Attaqwa dapat membuat jamaah merasa nyaman dalam melaksakan ibadah haji. Saran untuk mahasiswa yang akan melanjutkan penelitian Oleh karna itu untuk menyempurnakan penelitian ini maka saya sarankan kepada para peneliti berikutnya untuk mengkaji aspek tentang bimbingan konseling terutama mengenai aspek psikologi kepribadian. Harus lebih mematangkan konsep alur penelitian sebelum melaksanakan penelitian agar hasilnya lebih maksimal.

\section{DAFTAR PUSTAKA}

Arifin, I. Z. (2015). Bimbingan dan Perawatan Rohani Islam. Bandung: Mimbar Pustaka.

Alwisol. (2005). Psikologi Kepribadian. Malang: Penerbit Universitas Muhammadyah Malang.

Fadhilah, S. S., Hananto, I. (2014) Keefektifan Bimbingan Kelompok Dengan

Teknik Diskusi Untuk Mengubah Sikap Terhadap Layanan Konseling

Individual dalam Jurnal Counselium 1(3).

Kementerian Agama Republik Indonesia. (2014). Tuntunan Manasik Haji dan

Umrah. Jakarta: Direktorat Jendral. 
Mahfud, A. (2003). Petunjuk Mengatasi Stres. Bandung: Sinar Baru Algensindo Marlina, E. (2012). Motivasi Berpuasa Ramadhan dan Moralitas Remaja dalam Ilmu Dakwah: Academic Journal for Homiletic Studies, 6 (2), 250-265.

Munir, S. (2013). Bimbingan dan Konseling Islam. Jakarta: Amzah.

Prayetno. (2010). Dasar-dasar bimbingan konseling. Jakarta: Rineka Cipta.

Salahudin, A. (2010). Bimbingan dan Konseling. Bandung : CV. Pustaka Setia.

Satriah, L. (2015). Bimbingan konseling kelompok. Bandung: Cv. Mimbar Pustaka.

Setyaningrum, D., \& Setiawati, D. (2013). Pengaruh Persepsi Siswa Tentang Layanan Konseling Individu Dan Persepsi Siswa Tentang Kompetensi Kepribadian Konselor Terhadap Minat Memanfaatkan Layanan Bimbingan Dan Konseling dalam Jurnal Mahasiswa Bimbingan Konseling 3(1) Volume 3.

Syriati, A. (2010). Makna Haji. Jakarta:Zahra.

Walgito, B. (2010). Bimbingan Dan Konseling (Studi \& Karier). Yogyakarta: Andi

Wardiah, W. (2018) Optimalisasi Layanan Bimbingan Kelompok Dan Konseling Individu Dengan Menggunakan Media Power Point Sebagai Upaya Peningkatan Kebiasaan Belajar Siswa Kelas Ix-I Di Smp Negeri 1 Mataram Ganec Swara. 12 (1).

Wawancara Pribadi dengan Ketua Sekretaris Harian KBIH At-Taqwa. Fauzi, Ahmad. 27 Oktober 2017, Bekasi. 
